\title{
A REY-TESZTEK HAZAI TAPASZTALATAI
}

\section{KÓNYA ANIKÓ}

ELTE Pszichológiai Intézet, Budapest

E-mail: konya@izabell.elte.hu

\section{VERSEGHI ANNA}

Országos Orvosi Rehabilitációs Intézet, Budapest

E-mail: verseghi@izabell.elte.hu

\section{REY, TERESINHA}

Université de Genève

E-mail: reyter@vtx.ch

A Rey komplex ábrateszt fejlödési és klinikai alkalmazására a szakirodalom széleskörüen hivatkozik. Tanulmányunkban bemutatjuk André Rey genfi pszichológust, akinek neve leginkább Claparède és Piaget nevével társul. A Rey-tesztek arzenálja minden kognitív funkcióra kiterjed, tanulmányunkat a Rey komplex ábrateszt bemutatására korlátozzuk. Fejlödési és klinikai pszichológiai példák és a felnôtt neuropszichológiai példák egymást követik. A Rey-teszt új és új elméleti hátteret kap. Így a komplex ábra feladat a fejlödési megközelités mellett bevonult a bonyolult és a kognitív folyamatokat tekintve összetett végrehajtó (avagy frontális lebeny) feladatok közé.

Kulcsszavak: Rey komplex ábrateszt; emlékezet, kognitív fejlödés, kognitív neuropszichológia; végrehajtó funckió zavara

\section{A FEJLŐDÉSI ÉS A KLINIKAI MEGKÖZELÍTÉS ANDRÉ REY MUNKÁJÁBAN ${ }^{1}$}

Ki volt André Rey? Genfi pszichológus; 58 évet élt, az 1930-as évektől az 1960-as évekig jelentős helyet töltött be a francia gyermek- és klinikai pszichológiában. A fejlődéslélektano-

${ }^{1}$ KÓNYA A., Verseghi A. (1995) A. REY: Emlékezetvizsgáló feladatok előszava alapján. 
sok a Piaget-iskolához kapcsolják a nevét, a neuropszichológusok számára pedig a legjobb hívó szó a Rey komplex ábrateszt. Munkája a fejlődési klinikai pszichológia kikristályosodásához vezetett, amely kifejezés Claparède-től származik. Piaget mellett Rey Claparède és Lashley munkatársa, illetve tanítványa is volt.

Történeti távlatba helyezve, André Rey feltétlenül a genfi episztemológiai iskolához tartozik - még akkor is, ha kortársai azonnal felidézik a Piaget és közötte fennálló feszültségeket. Kétségtelen, hogy Piaget és ő ellentétes személyiségek voltak. A barátai, munkatársai, tanítványai - mindazonáltal egyaránt tisztelői által kialakított Rey-kép (Hommage à André Rey. Assotiation des amies d'André Rey, Charles Dessart, Bruxelles, 1967) egy érzékeny, nehéz, ugyanakkor kedves, finom s melegszívű embert ábrázol. Mindenkiben, aki mellette élt, vele dolgozott, meghatározó élményt hagyott. Amíg tehát a történeti távlat Rey-t a piaget-i iskolához sorolja, életrajzi perspektívában útjuk inkább keresztezi egymást. Szellemüket tekintve pedig egyikük elméleti, míg másikuk inkább módszertani alapokon építkezett. Piaget elméleti rendszerét magyar nyelvre is szép számban lefordított műveiből elég jól ismerjük. Vele szemben Rey-t inkább a gyakorlatban lehet megismerni. Az általa megformált eljárásokat olyan nagymértékü hajlékonyság jellemzi, amely csak a gyakorlatban s ezen túlmenve, sajátos miliőben születhetett meg.

A Claparède által megteremtett Klinikai Pszichológiai Intézet (1938), amelynek utódlása (1945) később reáesett, egy svájci kanton méretének megfelelő klinikai tömb (Service de Neurologie de l'Hopital de Genève) közepén állott. Ez az elhelyezkedés magyarázza meg azt a sajátos ötvözetet, ami Rey fejlődési-klinikai szemléletét jellemzi. A klinikai neurológia és a kísérleti pszichológia együttes hatást gyakorolt munkásságára. A Rousseau Intézet professzora volt. A sajátos szellemi ötvözet mutatója, hogy a fejlődéspszichológiai kurzusokkal egyidejűleg pszichofiziológiai kurzusokat tartott az orvosi karon. Összefoglalva, Rey egyaránt odafigyelt az általános pszichológiai, gyermekpszichológiai és patológiás folyamatokra.

A genfi iskolához, a személyes jelenlét mellett, talán legerősebben a klinikai megfigyelés módszere kapcsolja: az egyéni megfigyelésből, elemzésből történő következtetés a tipikusra. A módszer kapcsán elkülönítette az egyéni vizsgálatok céljára készített teszteljárásokat melyek a személy egyéni problémáját tartják szem előtt - a jól felépített tesztek „klinikai fegyvertárától”. Minthogy saját eljárásait sokkal inkább az egyéni problémák felderítésére alakította ki, mintsem valamely elméleti hipotézist a személyre alkalmazott volna; a fejlődéslélektani klinikai módszer kikristályosodása nagymértékben köszönhető személyének. A Rey-tesztek „menetközben” - a klinikai esetek által sugalmazva születtek meg. André Rey új és új eljárásokat vezetett be - illetve változtatott azokon gyakran egyik napról a másikra a vizsgált esetek kapcsán felmerült kérdéseknek megfelelően. Az esetek leggyakrabban a laboratóriumot körülölelő kórházból érkeztek. A cél - saját kifejezésével élve - a finom neurológia.

André Rey munkásságának ideológiája (tanítványa és barátja François Marchand elbeszélésére támaszkodva) az volt, hogy az elmélet a tényekben van. A nem túl rafinált, s ezáltal nem is túl elkötelezett elméletiség lehet a kulcsa annak, hogy a vizsgálati eljárások bármely elméleti korszakban kézbe vehetőek. Szemben azzal, amikor a vizsgálati eljárások kísérleti hipotéziseket igazolnak s izolált megismerési folyamatokat vizsgálnak, a Rey-feladatok bármily egyszerủek is - a mindennapi élet bonyolultságát igyekeznek megközelíteni. Ez utóbbi összeköti Reyt a neuropszichológia történetében az orosz A. R. Lurijával.

André Rey munkássága igen kiterjedt. A legszorosabb elméleti kapocs, amely a vizsgálatokat összetartja: az új feltételekhez történő időleges alkalmazkodás, amelyben Rey a tanulás rejtélyének megfejtését látta. André Rey figyelme a tanulási és emlékezeti folyamatok vizsgálataiban mindenekfelett az alkalmazkodás képességének eltéréseire irányult. A Piaget-iskolán belül képviselt nézetét jól mutatja „A gyermek gyakorlati intelligenciája” című 


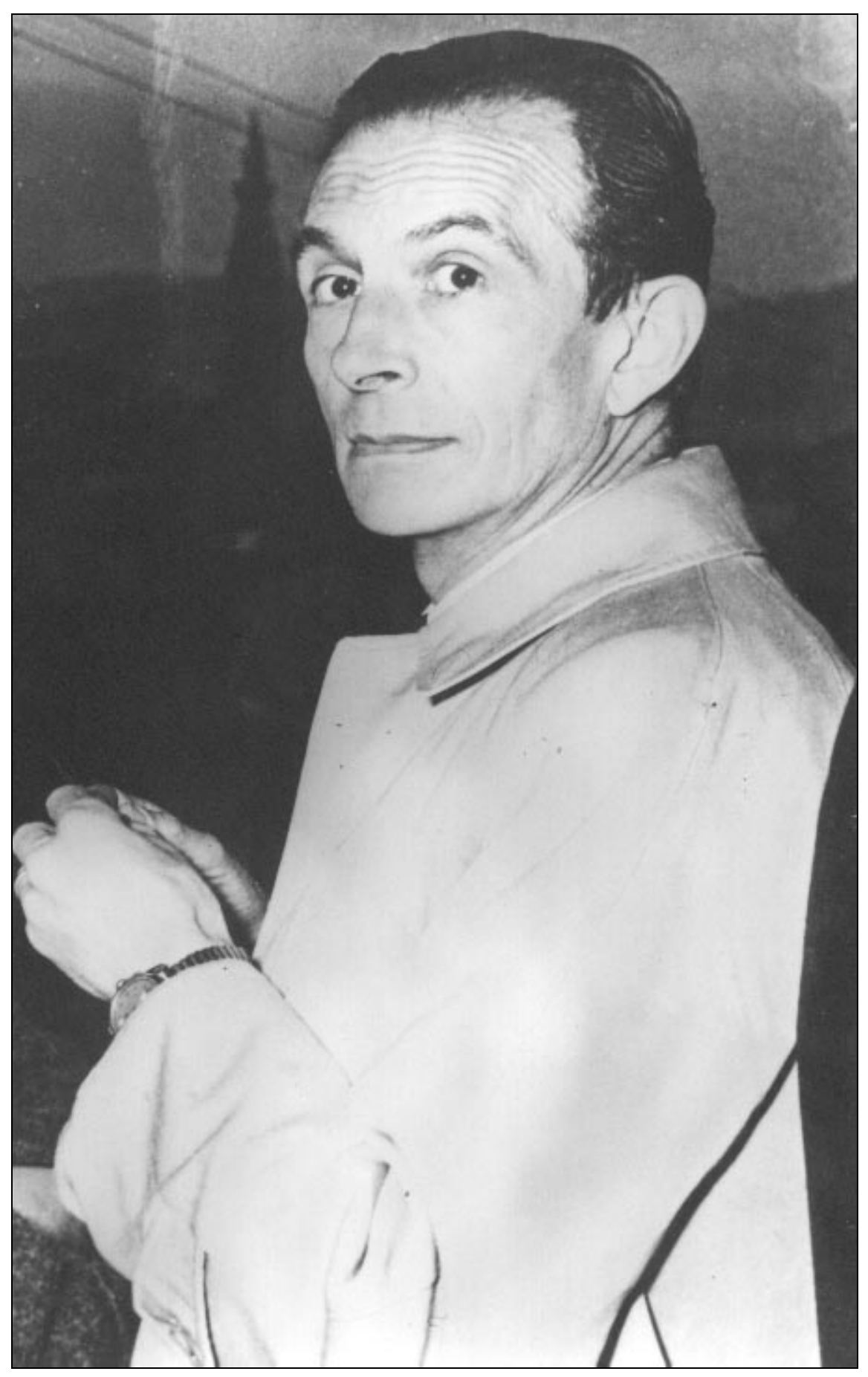

ANDRÉ REY 
munkája (L'intelligence pratique chez l'enfant. Paris, Alcan, 1935; lásd Piaget hivatkozását Reyre az Értelem pszichológiája. Gondolat, Budapest, 1993. című művében). Ebben az intelligenciát a mentális struktúrák állandó átszervezésének dinamizmusaként tekinti át. Az intelligenciáról vallott felfogásának lényege a problémával való találkozás során történő alkalmazkodás képessége. Ezzel összefüggésben a tanulékonyságot a mentális kapacitás kifejezésében diagnosztikus erejűnek tartotta. Figyelmeztet azonban arra az egyszerű és nem elhanyagolható tényre, hogy „ha egy gyerek még sohasem látott gyurmát”, azaz nem rendelkezik tapasztalattal, akkor nem azonos feltételekkel indul egy tanulási feladatban azokhoz képest, akik azt már megtapasztalták. Másként fogalmazva - az intelligencia mérése „feladatspecifikus”. A tanulásban fellelhető előrehaladás (amit a vizsgálati helyzetekben az ismétlések mutatnak) és a némileg megváltozott feladathoz való alkalmazkodás (interferenciahelyzetek) Rey számára a mentális hatékonyság mutatói. Rey a mentális hatékonyság mellett ugyanakkor számol a tanulékonyságra kiható járulékos tényezőkkel is, a fáradtság, érdeklődés és érzelmek hatásával. Több helyütt foglalkozott például a „pszichofunkcionális” teljesítmény mérésének homogenitásproblémájával. Azonos vizsgálati feltételek mellett (instrukció, rendelkezésre álló idő) az egyéni teljesítmény különbségeit tartósan meghatározó olyan tényezőkre hívta fel a figyelmet, mint amilyenek a szociális miliő, fiúk és lányok közötti eltérések, iskolázottság, nyelvi eltérésék.

\section{Magyar Rey memóriateszt-készlet}

Andre Rey tesztjeiből Mme Teresinha Rey segítségével állítottuk korábban össze az emlékezetiteszt-készletet, amely tizenhárom tesztet tartalmaz (KóNYA, VERSEGHI, 1995). A válogatás a klinikai tünetek sokféleségének megfelelő eljárásokból olyan készletet tartalmaz, amelynek célpontjában az emlékezeti folyamatok állanak. A magyar memóriakészletben található vizsgálati eljárások André Rey szellemében a tanulás és az emlékezés hajlékonyságát vizsgálják - szemben a fejlődési és klinikai vizsgálódásban elterjedt olyan hagyományos eljárásokkal, mint a szavak, számok vagy képek megjegyzése, melyeknek az emlékezeti folyamatokat illető indikációja igencsak nagyvonalúnak mondható. A klinikai területet tekintve az eljárások alkalmasak egyes sajátos hiányosságok megállapítására, de emellett a felépülés követésére is. Az interferencia-helyzetekre jellemző példát ad a gyűjteményünkben is szereplő lokalizációs próba, amely a téri labirintus feladatoknak kisgyerekekre kialakított változata. A feladat lényege az elforgatott téri helyzethez való átmeneti alkalmazkodás. Egyike a legkidolgozottabb és legelterjedtebben használt vizsgálati eljárásoknak, amely a klinikumban is elterjedt, a Rey kompex figura teszt, amelynek gyermek- (B) változatát összeállításunk is tartalmazza. A próba egyaránt kiterjed az észlelés és elaborálás folyamataira. André Rey emlékezetről vallott felfogását összefoglalja „Az emlékezés zavarai és pszichometriai vizsgálatuk" (Les troubles de la mémoire et leur examen psychometriques. Bruxelles, Dessart, 1966) című könyvében. Ebben a megismerés egymásba ékelődő folyamatait, ezek fejlődését és zavarait a figyelemmel és a fáradtsággal összefüggésben tárgyalja.

A memóriakészletbe általunk beválasztott próbák fejlődési és klinikai támpontokat adnak az emlékezet mủködéséhez. A kifejezetten felnőttek számára javasolt neuropszichológiai próbákat a válogatás nem tartalmazza, ugyanakkor az egészséges és a kóros együttes szemlélése átvezet a felnőtt klinikumba; a gyermektesztek erős leépülések esetén a felnőtt életszakaszokban is differenciáldiagnosztikus erejűek lehetnek. A fejlődési-klinikai kapcsolódás a Rey-tesztekben nyilvánvaló. Klinikai használhatósága miatt megemlítjük a Reykomplex teszthez hasonlóan széles körű szakirodalmi referenciával rendelkező Audio-verbális tanulási tesztet (AVLT - Audio-Verbal Learning Test). 
A tesztek némelyike csoportosan is alkalmazható. A tesztcsomag tájékoztató (nem standardizált) adatai az eredeti genfi mintán alapulnak. Több évtizedes adatokról van szó, ennek okán is csak tájékoztatóak. Minthogy azonban a feladatok elvégzése nem mereven előírásszerű, elsősorban a szakértői tapasztalat a mérvadó a teljesítmény megítélésében, a feladatok mindenkor jól használhatóak az emlékezeti problémák felderítésében, körülhatárolásában.

A Rey-tesztek ma is elterjedt használata a kognitív funkciók általuk történő differenciálhatóságával magyarázható. İgy például a Rey komplex ábrateszt a fejlődési, neurológiai és pszichiátriai szakirodalomban egyaránt fellelhető. A tesztek ízére használatuk közben lehet rátalálni. A szó szoros értelmében nem tesztek, hanem az egyéni vizsgálat alapjául szolgáló vizsgálati eljárások. Erős mondanivalójuk a módszertan életszerűségének igénye, valamint az egészséges és a kóros megismerési folyamatok együttes látásmódja. Hazai párhuzamot találva, Rey munkássága Ranschburg Páléra emlékeztet.

\section{TAPASZTALATOK: \\ A REY KOMPLEX ÁBRATESZT BEMUTATÁSA}

E tanulmányban a Rey-tesztek bemutatását a szakirodalmilag leghivatkozottabb Komplex ábratesztre alapozzuk, néhány hazai tapasztalattal is szemléltetve a teszt által bejárható elméleti és gyakorlati utakat. Az ábra könnyebb és nehezebb változatát az 1. ábrán szemléltetjük, az értékelés szempontjainak feltüntetésével. A „könnyebb” és „nehezebbről” gondolkodhatunk fejlödési és klinikai értelemben. A figura komplex, furcsa és idegen. Egyben kell látnunk és ugyanakkor analizálnunk a részeit ahhoz, hogy az első feladatban lemásoljuk, majd a másodikban emlékezetünkből téri-vizuális képzeletünk által felidézzük. A felidézés általi vizuális rekonstrukció azonnal és késleltetve is megtörténhet. A rajz másolásának perceptuális szerveződési feladata sokban eltér az emlékezetből történő rajzolástól - ezt alátámasztja, hogy a Bender-teszttel tapasztalataink szerint csak a másolás teljesítménye mutat megfelelést.
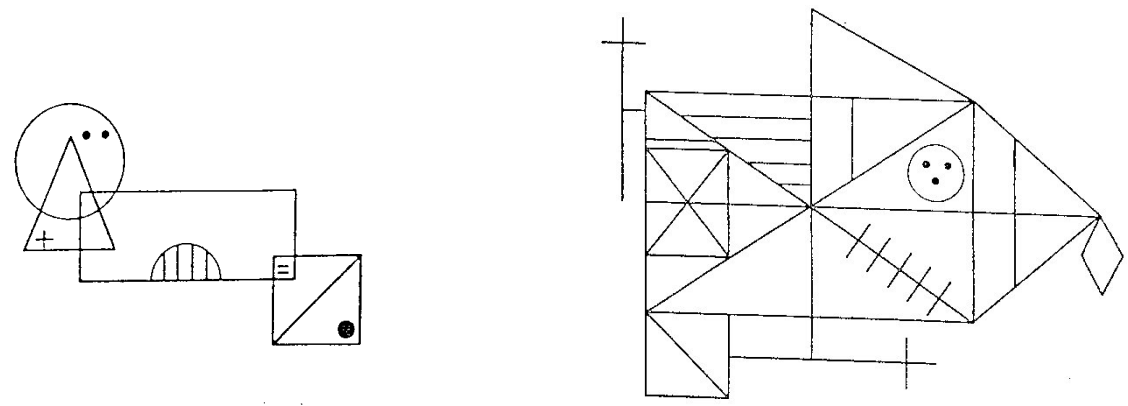

1. ábra. Az értékelés szempontjai a másolásnál és az emlékezeti reprodukciónál

1. lerajzolt ábraelemek száma; 2. az ábrarészek arányossága; 3. az ábrarészek kapcsolódása; 4. reprodukált apróbb részletek száma (másodlagos elemek száma/helyzete) 
Az egyszerübb ábra értékelésének leírását lásd magyarul KÓNYA, VERSEGHI (1995), a nehezebb változat értékelése REY (1945/1959) és munkatársa OSTERRIETH (1945) nyomán alakult ki. ${ }^{2} \mathrm{E}$ két név összefüzésével a tesztre való hivatkozás gyakorta Rey-Osterrieth komplex ábratesztként történik; melyen belül a nehezebb ábra az $A$, a könnyebb a $B$ jelölést kapta. Amíg a teszt megszületése Rey-nek köszönhető, a rajzolás típusainak kidolgozása és ennek fejlődési szintekhez való rendelése az utóbbi szerző munkája. A firka, sematizáció, a komplexitást jól utánzó konfúzió (benne esetlegesen jó elemekkel), a részletek egymás mellé rendelése, az egész figurát körülvevó kontúrrajz, majd a téglalap tartóelemére (esetleg néhány szorosan hozzátartozó elemmel együtt) épülő megoldások keverednek, illetve dominánssá lesznek az egyes életkorokban - hozzávetőleg a felsorolt sorrendben.

A Rey komplex ábrateszt $A$ és $B$ változatának technikailag újabb értékelési módszerét adja MONTHEIL (1993). Az $A$ változat angol kézikönyvének egy mai változata (Meyers, J. E., Meyers, N. R., 1995) ugyancsak tartalmaz technikai újításokat, valamint szakirodalmi áttekintést, újabb fejlődéspszichológiai és klinikai öszszehasonlító eredményeket.

\section{A Rey komplex ábrateszt A és B változata a fejlődési vizsgálatokban}

A szimmetriára való törekvés és a perszeveráció a gyerekrajzokban visszatérő megfigyelés; ugyanígy az is, hogy a formális, azaz a geometriai ábrákat elemző és a topográfiai viszonyok alapján szintetizáló megoldások helyett gyakran találkozunk a piaget-i értelemben vett szinkretizáló gondolkodással; amely halmazszerủen kezeli az elemeket. A Rey komplex ábra $A$ és $B$ változata mindezek figyelembevételével mást hoz ki a gyerekrajzokból, ezért külön-külön foglalkozunk fejlődési alkalmazásukkal.

A komplex ábra A változatának bemutatásában Philippe Wallon és Claude Mesmin tanulmánykötetére támaszkodunk (WALlON, MESMIN, 1998). A nehezebb ábra használata gyereknél előtérbe hozza a sematizációt, melynek alapján a nevezett kötet szerzői a szigorúbb pontozás helyett projektív értelmezést adnak. A fejlődési/klinikai csoportos és esettanulmányok tanulsága szerint nem feltétlenül szimbolikus, sőt egyenesen geometriai gondolkodást kell keresnünk a rajzok mögött. A személyek általában észreveszik, hogy mi van - nevezzük a borítékban benn és kívül. Ez a forma jóságából és a projekcióból is származik. A tartalom nem puszta kitöltés; bár a figura értelmetlen, belevihető jelentés - például háztető, repülő, hal - és más megszokott, ismert sémák. Maga a rajz nem nevezhető meg, de részei igen; melyek akár áthelyeződnek vagy a rajzban megduplázódnak. A gyerek részekre bontja a komplex figurát és teret ad gondolatainak - a rajz nem szimmetrikus, de rájátszik a szimmetriára a képzelet által. A kultúra is szerepet kap a megoldásokban, melynek során a gyermek szabadon, többé-kevésbé tudatosan alkot.

\footnotetext{
2 Magyarországon 15 éve használjuk sikerrel a komplex ábra $A$ változatát a felnőtt klinikumban, a neurológiai szindrómaanalízis vizsgálat részeként (például VERSEGHI, VINCZE, 1989).
} 
Az összefoglaló kötetben WALLON (1998) azt vizsgálja, miként nyilvánulnak meg a pszichológiai és neurológiai tényezők az ábrázolásban. Ennek kimutatására pszichológiailag problematikus 5-8 éves gyerekek rajzait elemezték egészséges gyerekek rajzaival együtt; mindannyian bevándorlók gyermekei voltak. A vizsgálat alkalmazta a Rey komplex ábrateszt mellett a Goodenough-féle emberrajzot. A vizsgálat egyik célja a patológiás és pszichológiailag problémás esetek elválasztása, ami a pszichológus és a tanár megfigyeléseit egészíti ki. A francia anyagból kiemelt esettanulmányokat ábraként mutatjuk be. Az ábra szervezésének hiányát mutató két eset $(2 a$ ábra $)$ ezt a diagnosztikus lehetőséget példázza. A további két eset szemléltetése ( $2 b a ́ b r a)$ az ábrázolás egy-egy sajátosságát (a méretet és a szimbolikus ábrázolást) emeli ki az iskolai és pszichológiai zavarok jelzőjeként.

Az ábra szervezésének hiánya

DJIO (6 év 2 hónap, fiú) - a másolás vonalai kuszák (balra), a megfigyelés szerint kidolgozott stratégia nélkül részről részre halad. A stratégia hiányával magyarázhatóan az emlékezés sikertelen. Az emberrajz (jobbra) egyszerủ de szabályos. A pszichológiai jellemzés szerint gyereknek az új feladatok nagy nehézséget okoznak, a rajzot is figyelembe véve patológiás eset.

DENA (6 év 5 hónap, lány) - a másolt ábra erősen torzult (jobbra), az emlékezés a lapot felezve épphogy tartalmaz elemeket (balra). A pszichológiai jellemzés szerint a kisgyerek figyelme elkalandozik. Iskolai problémái vannak, éretlen (amit az emberrajz is mutat), ám folyamatosan fejlődik.

$2 a$ ábra

Kis méretű, jól strukturált ábra 


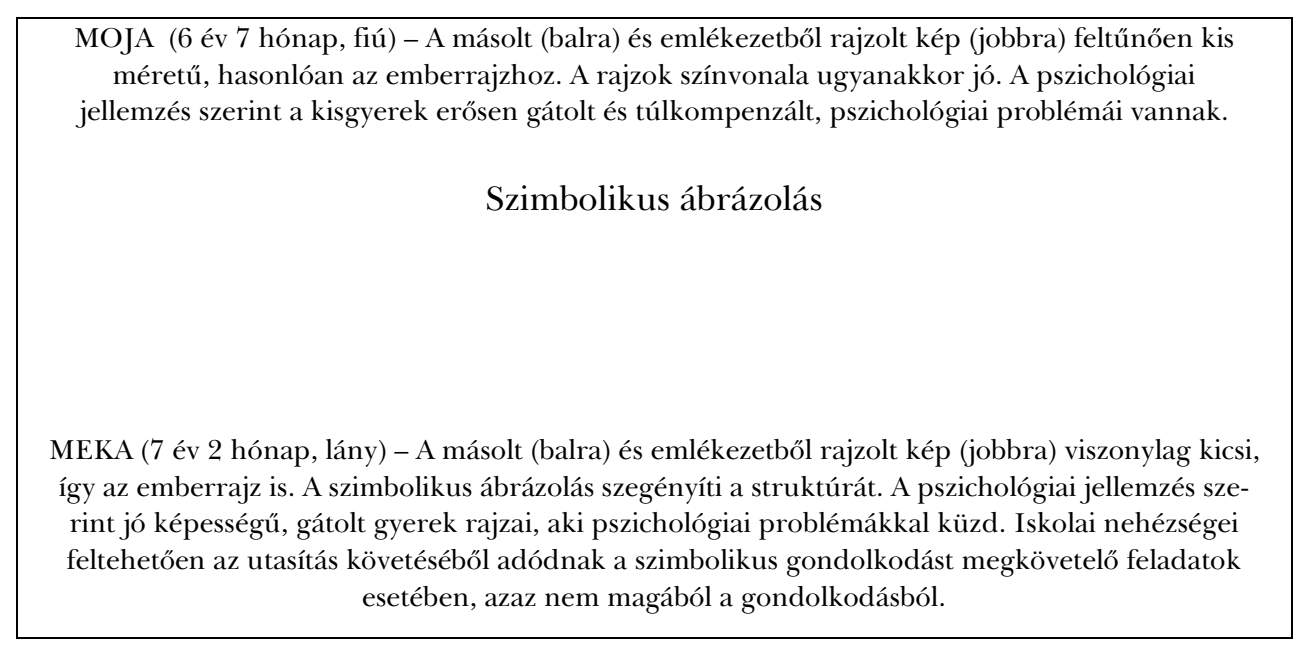

$2 b a ́ b r a$

A komplex ábra B változatának bemutatásához saját adatainkból merítünk. A hazai gyakorlatban óvodás és kisiskolás gyermekeknél az ábra egyszerűbb, gyermekeknek szánt változatát használjuk, amely az alakzat szintézise szempontjából - az ábrázolás szimbolizmusa tekintetében - megfelelőbbnek látszik. Alkalmazását alátámasztja, hogy ebben az egyszerű tesztben a gyermekek nyolcéves kor felett érik el a meglett felnőttkori teljesítményt, s ennek előtte jól követik az eredmények a kognitív fejlődést.

Az alábbiakban Damó Eszter vizsgálati anyagára hivatkozunk, aki nagycsoportos óvodás gyerekeket vizsgált (81 gyerek, életkori átlag hat év) a komplex ábra egyszerúbb (B) változatát alkalmazva. A 3. ábra a megkülönböztetés lehetőségét szemlélteti a komplex ábra B változata segítségével.

\begin{tabular}{|lc:cc|}
\hline K. B. & Másolás & G. J. & Másolás \\
& $(5,5$ pont $)$ & $(29$ pont $)$ \\
\hline
\end{tabular}




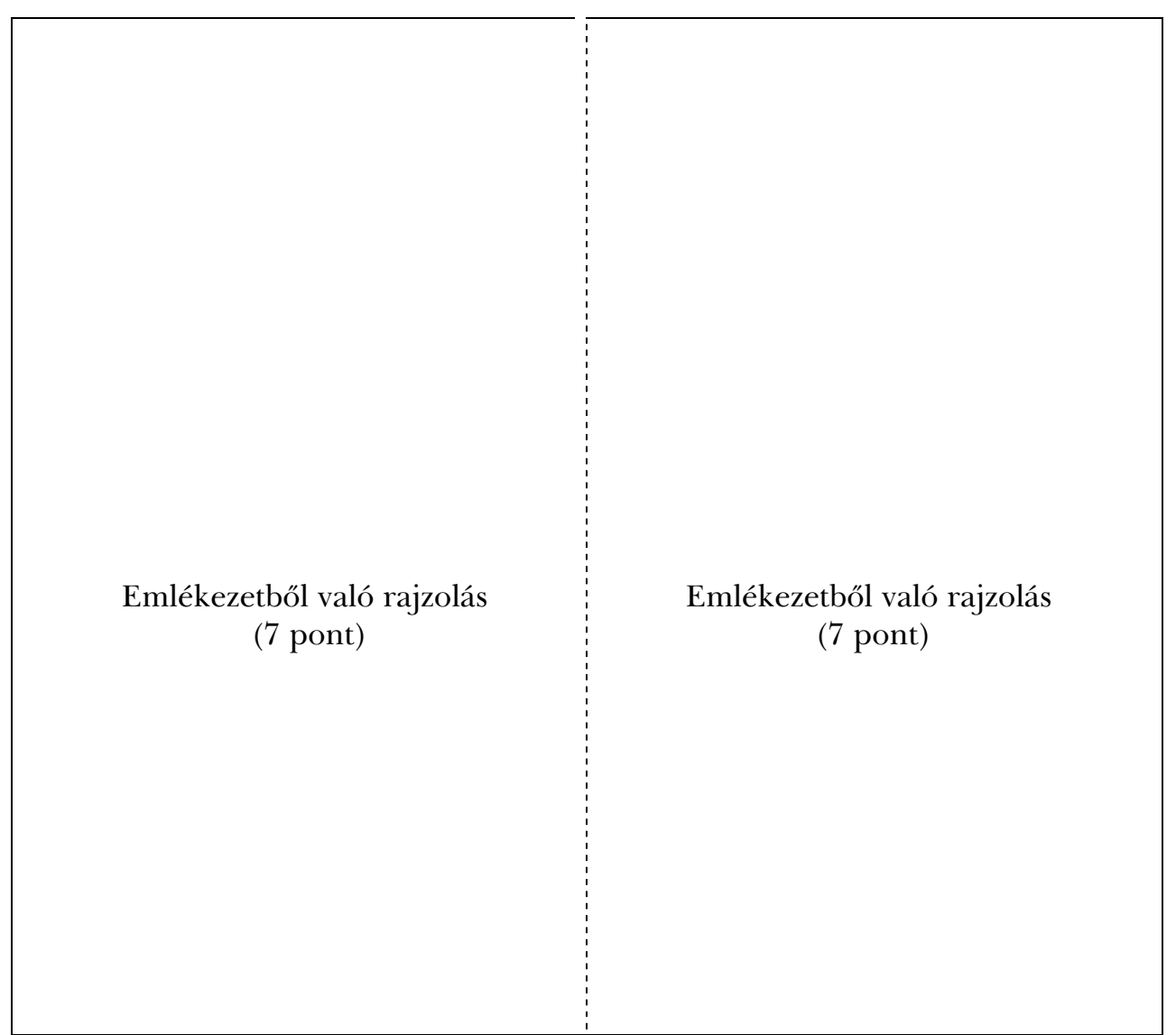

3. ábra. A bal oldali (K. B., 6 év 6 hónap, fiú) és a jobb oldali rajzok (G. J., 6 év 3 hónap, fiú) szemléltetik, hogy óvodás korban a Komplex ábrateszt $\mathrm{B}$ változata alkalmas fejlődési különbségek kimutatására

A fenti vizsgálat további, ösztönző megfigyelései szerint, az ábramásolás és reprodukció mutatói (részletek száma, arány, kapcsolódás, másodlagos elemek) különkülön is eltérnek a gyerekek között, ami megalapozhatja az 5-6 és 6-7 éves kor közötti fejlődési ugrást. Az óvodások vizsgálata kimutatta a másolás és az emlékezeti reprodukció pontszámbeli teljesítményének összefüggését is. A két próba kapcsolata $\chi^{2}=38,3 ; \mathrm{f}=9 ; \mathrm{p}<0,001$. Ugyanakkor a variancianalízis a csoportok között növekvő teljesítménycsökkenést mutatott a két próba között a jól másolók irányában - akiknek „volt miből rontaniuk”. A másolás teljesítménye általában felülmúlja az emlékezetből rajzolásét: összehasonlításként a jól és a közepesen másolók esetében az emlékezés 4-5 ponttal romlik a vizsgált életkorban. Azonban ha a teljesítményt négy kategóriába osztjuk (gyenge, átlagos alsó, átlagos felső, jó) a gyerekek közel fele mindkét csoportosításban azonos helyre kerül. A gyerekek 
teljesítménye ebben az életkorban igen változó - így az emlékezetből való rajzolás időnként jobb is lehet a másolásnál. A másolás és a felidézés közti esetenkénti feljavulást annak fejlődési jeleként tekintjük, hogy a gyerek képes elszakadni az ábrától, és azt nagyobb egységként szemlélni. Ez a fejlődési indikáció még igazolásra vár, izgalmas feltevésként említjük itt meg. Mindenesetre iskolás életkorban hasonló jelenség a $B$ formát használva már nem figyelhető meg.

A hivatkozott francia vizsgálatokhoz hasonlóan a vizsgálat emberrajzot is kért, megfeleltetve a figuratesztben mutatott teljesítményt az emberábrázolás színvonalának. A komplex ábra és az emberrajz összefüggése statisztikailag is alátámasztást kapott. A Rey-teszt összesített eredményei mind a másolás, mind a reprodukció terén szoros korrelációt mutatnak a Goodenough-skála eredményeivel $(\mathrm{r}=$ $=0,34 ; \mathrm{r}=0,36 ; \mathrm{p}<0,05)$. Az egyes mutatók tekintetében az ábrarészek egymáshoz kapcsolódása korrelált az emberrajz eredményeivel a másolásban $(\mathrm{r}=0,38$; $\mathrm{p}<0,05)$ és a reprodukcióban $(\mathrm{r}=0,51 ; \mathrm{p}<0,001)$.

A komplex ábra B változatának fejlődési eredményei értelmezhetőek a feladatok összehasonlítása által is. Tájékozódó vizsgálataink során Vajger Éva 8-9 éves gyerekeknél plafonhatást talált e könnyebb komplex ábra változatában (hasonlóan a lokalizációs próbában) - amíg a szin-forma megfelelés teszt feladata továbbra is érzékenyen differenciált a gyerekek között (e két utóbbi feladat leírását lásd KóNYA, VERSEGHI, 1995). A mentális erőfeszítés magyarázza a feladatok érzékenységének eltérését. Eszerint: a figura-forma teszt a másik két feladathoz viszonyítva nagyobb műveleti erőfeszítést kíván. Ez az elméleti megközelítés átvezet a neuropszichológiai értelmezéshez.

\section{A REY KOMPLEX ÁBRATESZT $A$ ÉS $B$ VÁLTOZATA A NEUROPSZICHOLÓGIÁBAN}

A neuropszichológiához az elmúlt időszakban - a kerekség kedvéért tíz évben hozzátapadt a kognitív jelző, amely azt jelzi, hogy a kognitív pszichológia alapelméletei kipróbálták értelmező erejüket ezen a területen. Ebben a megközelítésben, a komplex ábra perceptuális szerveződést és emlékezést vizsgáló tesztjét melyet André Rey a neurológiai esetek azonosítására fejlesztett ki (REY, 1942) - a végrehajtó funkciót mérő tesztek (Wiskonsin Kártyaszortírozási teszt, fluenciatesztek stb.) sorában találjuk. A komplex teszttel Rey az emberi cselekvés, gondolkodás hajlékonyságát, alkalmazkodóképességét kívánta nézni - ami a végrehajtó funkció fogalmának taglalása szerint (például RABBITT, 1997) szándékolt tervezést, irányítást, a feladat végzésének tudatos monitorozását és gyakran a válaszok, képzetek gátlását és irányváltást igénylő feladatot jelent. A magasabb szintű észlelés rendszereinek igénybevételét tekintve a vizuális/téri vázlat értelemszerúen szükséges az ábra megtervezésében és fenntartásában; a fonológiai/artikulációs hurok pedig a verbális stratégiákból kikövetkeztethetően kell hogy részt vegyen a figura szervezésében. A Rey-figura tehát olyan komplex feladat, amelynek elvégzése a munkamemória műveleti rendszerét koordináltan foglalkoztatja. A feladat által kért vizuális konstrukció behatóbb fejlődési és klinikai elemzése e tekintetben még 
hátravan. A jobb oldali hátsó lebeny sérülések alacsony teljesítményben jelentkező hatása, amely az ellenoldali sérüléshez képest jóval erősebb, például a tériség szervező ereje mellett szól. A komplex ábra hibatípusai ezt igazolni látszanak.

Tesztbemutatásunkban most ugyancsak a komplex ábra B változatára támaszkodunk. E könnyebb változat alkalmazásának klinikai lehetőségét az alábbiakban a Dezső Linda által végzett csoportos vizsgálat által mutatjuk be, amely a Korszakov-betegek erőteljes retrográd amnéziáját igazolja a komplex ábra feladat által. A betegek a DOTE Pszichiátriai Klinikán, a debreceni Kenézy Gyula Kórház Pszichiátriai osztályán, a Nyírő Gyula Kórház Pszichiátriai osztályán és az ORFI Alkohológiai osztályán álltak kezelés alatt. A vizsgálat alátámasztja a krónikus alkoholista és Korszakov-szindrómás diagnosztikus csoportok elkülönítését. (Tizenöttizenöt személy került be a kontroll- és a krónikus alkoholista csoportba, a tiszta képű Korszakov-szidrómás betegek száma pedig hat fó.) Az 4. ábra jól mutatja az alkoholista betegek - s ezen belül is a Korszakov-csoport - teljesítményének csökkenését a másolás és a felidézés között. A másolás és az azonnali 3 perces felidézés visszaesésében jelentős volt a különbség a csoportok között. A statisztikai összehasonlításban az egyszerű ábra változat használata okán egy második (nyolcéves) kontrollcsoport is szerepelt, 15 fővel. A kétszempontos VA eredménye alapján a

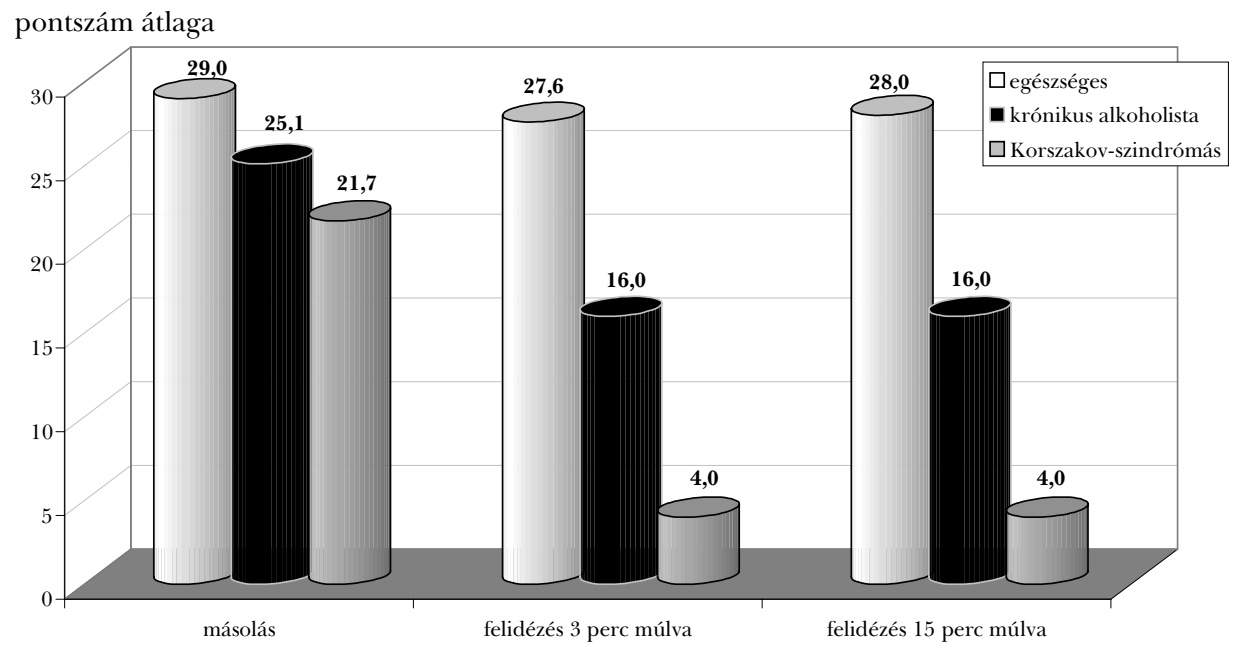

4. ábra. A másolás és az emlékezeti felidézés teljesítménye egészséges és alkoholista személyeknél a Rey komplex ábrateszt egyszerű változatával vizsgálva

másolás és az azonnali felidézés különbsége az így már négy csoport között F $(3,47)=43 ; 15 \mathrm{p}<0,01$ szinten különbözött. Habár a különbség megmaradt, figyelemre méltó, hogy a romlás 15 perc múltán nem fokozódik a krónikus alkoholistáknál sem, ahol a teljesítmény ezt még megengedné. Tartalmilag is majdnem azonos marad az ábra kitöltése a beteg csoportoknál; ami arra enged követ- 
keztetni, hogy az elemi geometria ismeret, amire az első felidézés támaszkodik (például kör és háromszög, lásd 5. ábra) az emlékezés szempontjából megbízható támpont.

Másolás

5. ábra. Korszakov-szindrómás beteg (Gy. K.) vizsgálata a Rey komplex ábrateszttel
Felidézés három perc múlva

A klinikai vizsgálatok többnyire esettanulmányok, melyek számos neuropszichológiai eljárást használnak egymás mellett. PARKIN és STAMPFLER (1995) a frontális lebeny diszfunkciójaként értelmezték leírt esetüknél a Rey-Osterreith-ábra (A forma) felidézésének gyengeségét, megerősítve azt ismert tárgyak lerajzolásának képtelenségével (például bicikli). Többek közt használták a fentebb megemlített végrehajtófunkció-teszteket, a hívószavas önéletrajzi emlékeztetést, valamint az Ismert személyiségek tesztet: mindezekben hasonlóan gyenge teljesítményt kaptak. A szerzők szerint a szemantikus, epizodikus és képi emlékezeti teljesítmény általában gyengül a retrográd amnézia klinikai eseteiben. Egy másik, WILSON és WEARING (1995) által publikált tanulmányban a mély amnézia Rey-Osterreithtesztben mutatkozó jelzését megerősíti a Rivermead viselkedéses memóriateszt és az Önéletrajzi emlékezeti interjú. A vizuális rekonstrukció zavara társulhat tehát az amnézia más, általános tüneteivel.

Tanulmányunkban az eljárást és annak két változatát kívántuk bemutatni. Kiemelt figyelmet szenteltünk a komplex ábra $B$ változatának, amely a mai szakirodalomban háttérbe került és amelynek fejlődési és klinikai alkalmazását igyekeztünk szemléltetni. Általánosságban tekintve a Rey komplex ábrateszt fejlődési és klinikai próbája jelzi a vizuális észlelés és emlékezet zavarait, a komplex jelző nemcsak az ábrára, hanem a vizuális konstrukciót érintő folyamatok együttesére is érthető. 


\section{IRODALOM}

Kónya A., Verseghi A. (1995) A. REY: Emlékezetvizsgáló feladatok, Pszicho-Teszt, Budapest

Meyers, J. E., Meyers, N. R. (1995) Rey Complex Figure Test and Recognition Trial. Professional Manual. Psychological Assessment Resources, Inc., USA

Montheil, M. C. (1993) Manuel de la feuille dépouillement de la figure complexe de Rey Figures $A$ et $B$. Les Editions du Centre de Psychologie Appliquée, Paris

Osterrieth, P. A. (1945) Le test de copie d'une figure complexe. Archives de psychologie, XXX, 205-353.

Parkin, A. J., Stampfer, H. G. (1995) Keeping out the past: a study of temporary memory loss. In Campbell, R., Conway, M. (eds) Broken memory, Case Studies in Memory Impairment. Oxford

Rabiti, P. (1997) (ed.) Methodology of frontal and executive function. Psychology Press, Oxford

REY, A. (1942) L'examen psychologique dans les cas d'encephalopathie traumatique, Archives de psychologie, XXVIII, 286-340.

Rey, A. (1945/1959) Test de copie de d'une figure complexe de A. Rey, Manuel. Centre de Psychologie Appliquée, Paris

Verseghi A., Vincze E. (1989) Egy gyors neuropszichológiai szűrővizsgálat. Magyar Pszichológiai Társaság IX. Országos Tudományos Konferenciája, Budapest

WALlon, Ph. (1998) FCR et difficultés psychologiques. In Wallon, Ph., Mesmin, Cl. (eds) La figure de Rey. Une approche de la complexité. 65-126. Les pluriels de Psyché, Paris

Wallon, Ph., Mesmin, Cl. (1998) (eds) La figure de Rey. Une approche de la complexité, Les pluriels de Psyché, Paris

Wilson, B. A., Wearing, D. (1995) Prisoner of consciousness: a state of just awakening following herpex simplex encephalitis. In Campbell, R., Conway, M. (eds) Broken memory, Case Studies in Memory Impairment. Oxford

\section{INTRODUCTION OF THE REY COMPLEX FIGURE TEST}

\section{KÓNYA, ANIKÓ-VERSEGHI, ANNA-REY, TERESINHA}

The developmental and clinical use of the Rey Complex Figure Test is often referred to in neuropsychological literature. The paper introduces the work of André Rey whose name is mostly associated with Claparéde and Piaget. Although Rey tests cover the whole range of cognitive functions, this paper only discusses Rey Complex Figure Test. Examples of normal and pathological children and adult neuropsychological patients are reported. The Result with Rey Complex Figure Test are discussed within the theoretical framework of executive disorders.

Key words: $\quad$ Rey Complex Figure Test, memory, cognitive development, cognitive neuropsychology, executive disorders 